\title{
An Inquiry into the Lexical Affinities between Arabic and Yorùbá Languages
}

\author{
Kazeem Adebayo Omofoyewa, PhD \\ (Department of Arabic and Islamic Studies/ University of Ibadan, Nigeria)
}

\begin{abstract}
There are indeed some evidences of interplay between Arabic and Yorùbá languages in spite of the distance in space between the two cultures. This invariably shows the universality of language which erodes the constraints of distance and time on social organisation and interaction. The nexus between both languages is evident in the multitude of Arabic loan words and expressions found in Yorùbá language. This paper, therefore, gives an insightful examen of the Arabic and Yorùbá languages, their speakers, as well as the varieties of both languages, vis-à-vis the standard and colloquial ones. It also probes into the influence of Arabic on Yorùbá language and culture, and equally highlights the Arabic loan words in Yorùbá language in a bid to establishing the relationship between the two languages. The paper employed the sampling method and the data were content analysed.
\end{abstract}

Keywords:Inquiry, lexical affinities, Arabic and Yoruba languages.

\section{The Arabic Language and its Speakers}

Arabic belongs to the Semitic language family which are as Aramaic, Hebrew, Amharic and South Arabic like Sabean, Himyaritic and others, most of which are now 'dead' or almost 'dead'. The Semitic languages have a recorded history which goes back thousands of years - one of the most extensive continuous archives of documents belonging to any human language group. ${ }^{1}$

Arabic has assumed its place as an international language twice - during the Golden Age of Islam and in our modern times. ${ }^{2}$ An examination of the literary activities between $9^{\text {th }}$ and $12^{\text {th }}$ centuries reveals that more works: philosophical, medical, historical, religious, astronomical and geographical were produced in Arabic than through any other tongue. ${ }^{3}$ Currently, Arabic is one of the six official languages of the United Nations (UN). Other languages being: English, French, Mandarin (a standardized variety of Chinese), Russian and Spanish. It has also been made a working language in the African Union (AU), formerly known as Organisation of African Unity (OAU). Of recent, it has been reinstated as a second tongue in the Republic of Iran, Pakistan, as well as the Southern part of the Philippines. ${ }^{4}$

Furthermore, Arabic has become the lingua franca of many Muslims across the globe. Right from the conquest of the Muslim armies at the early stage of Islam, Arabic has been the language of the Qur'an and Islam par excellence. It has since served as the suitable tongue with which a Muslim could approach Allah in worship other than supplication, as no one who embraces Islam could avoid, at least, some use of Arabic. ${ }^{5}$ None of the world known languages, whether Greek, Latin, etc. has ever attained world stature as did classical Arabic, a language that is well suited to interact favourably with other idioms. According to Joel Carmicheal:

The possibilities in Arabic for the use of figurative language are endless; its allusiveness tropes and figures of speech place it far beyond the reach of any other language... Arabic loses on translation but all other languages gain on being translated into Arabic. ${ }^{6}$

Today, speakers of Arabic language known as 'Arabs' constitute most of the population of Algeria, Bahrain, Egypt, Iraq, Jordan, Kuwait, Lebanon, Libya, Morocco, Oman, Qatar, Saudi Arabia, Sudan, Syria, Tunisia, United Arab Emirates (UAE), the West Bank and Yemen. However, they could also be found elsewhere in the world. There is no gainsaying the fact that Arabic is still expanding world-wide. About 300 million use it as a mother tongue and another, numbering about 800 million as a religious language. ${ }^{7}$ Indeed, it continues to be a living vibrant language, revered by Muslims and non-Muslim Arabs throughout the world. ${ }^{8}$

\section{Varieties of the Arabic Language}

Practically, there are two living varieties of Arabic coexisting in the Arab countries. These are the classical Arabic (العبية الفصحى) al-'Arabiyyatul-Fushā (Standard Arabic) and colloquial language (العامية) al'Ámmiyyāh (Spoken Arabic dialects). While the former serves as the vehicle for all written communication throughout the whole Arabic - speaking world owing to its uniformity and mutual intelligibility, the latter varies greatly from one locality to another, even amongst the elites. ${ }^{9}$ At this juncture, it is worthwhile to say categorically that standard Arabic is not the native language of any speakers. This is because nobody is brought 
up speaking standard Arabic. Conversely, everyone starts out learning the dialect ( عامية - 'Ammiyyah) of the area in which they live, and as they proceed to achieve literacy in an educational environment, they subsequently learn standard Arabic (فصحى - Fushā), ${ }^{10}$ a simplified version of Qur'anic Arabic which unites the people. It is indeed, the written language of all the Arab lands, used in newspapers, schools, television and radio. ${ }^{11}$

Among myriad of dialects existing in the Arab countries, the dialect of the Quraysh of the Northern Adnanite Arabic language was regarded as the purest and richest, vocabulary-wise. Nowadays, it is the mostly used Semitic tongue, surpassing all others in its wealth of synonyms, harmonious patterns, concision clarity and eloquence. ${ }^{12}$ The fact being that, the Quraysh were, as at then, far removed on all sides from the lands of the non-Arabs who could easily distort or pollute their language. Next to them are their neighbouring tribes, the

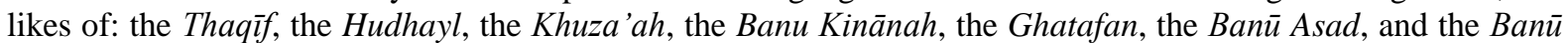
Tamim. However, the linguistic habit of other tribes living farther away from the Quraysh was not perfect due to their contact with non-Arab Persians, Byzantines and Abyssinians. These tribes include the Rabi 'ah, the Lakhm, the Judham, the Ghassan, the Iyād, the Quda'ah, and the Arabs of Yemen.

In fact, what strengthens distortion, pollution, or corruption of Arabic language particularly after the Muslim conquest was that the then upcoming generation were at the cross road as they heard other ways of expressing their minds than the ways the Arabs did. The proliferation of the non-Arabs in the Arab communities gave these classes of people the liberty to express themselves the way they liked, as they adopted new ways of expressing themselves from both sides and thus brought about a new linguistic habit which was in contrast with the first one.

Besides, the Quraysh were the custodians of Islamic sanctuary and as well the major controller of Arabian economy. The Quraysh have been playing prominent role in hosting other neighbouring Arabian tribes in the annual fare of ${ }^{\complement} U k \bar{a} z$ of the pre-Islamic era.

\section{Yorùbá Language and its Speakers:}

Yorùbá language belongs to the Kwa family within the Niger-Congo phylum of African languages. ${ }^{13}$ It is spoken mainly in the LOOOOE ${ }^{14}$ states (Lagos, Ọyộ, Ộsun, Ògùn, Òndó and Ėkitì) which constitute the old Western state of Nigeria. In addition, in most parts of Kwáà̀ and some parts of Kogí states of Nigeria, Yorùbá is also spoken. It is regarded as one of the major languages in the country, others being Hausa and Igbo. The speakers of Yorùbá are also found outside the western boundaries of Nigeria; in the south-eastern part of the Republic of Benin (formerly Dahomey) and Togo ${ }^{15}$ Akinkugbe (1978)says that its speakers are also found in other West African states and beyond:

Yorùbá communities are reportedly found in other West African countries like Sierra Leone and Ghana. Their existence in these areas has resulted partly from migration from Nigeria, and partly from resettlement of slaves in free town, Sierra Leone, after the slave trade of between the $16^{\text {th }}$ and $19^{\text {th }}$ centuries. It is interesting to note that Yorùbá communities are also reportedly found in the West Indies and South American, particularly in Cuba and Brazil. These communities are offshoots of slaves transported from the West African coast during the slave trade. ${ }^{16}$

The fact that Yorùbá is still spoken in Brazil and Cuba has long been noted in Turner (1958) ${ }^{17}$ who argues that a number of surviving speakers of Yorùbá language can be found in the United States of American as well as New World regions. The present speakers of Yorùbá in Brazil and Cuba, in the words of Hunt, are known as Nago and Lucumi respectively. ${ }^{18}$

Watkins (1972) also avers that the descendants of slaves in Cuba and Brazil have really helped in the preservation of Yorùbá. According to him, people whose ancestors entered Brazil as free immigrants are not left out of this giant stride. He equally observes that the specimens of Yorùbá culture are generally less difficult to obtain in West African peoples than those in many other peoples of Saharan Africa. ${ }^{19}$

Recent studies have also revealed that Yorùbá is gradually receiving more attention abroad than it is at home (that is, on the shores of Nigeria). A Yorùbá scholar, Adewole avers:

Yorùbá is one the minority languages in the United States of America. ...the Universities where Yorùbá is being studied in United States as a foreign language are more than the Universities where Yorùbá is being studied in Nigeria. Whereas there are about ten Universities in Nigeria where Yorùbá is being taught as a subject, there are about sixteen Universities in the United States where students learn Yorùbá. Some of these Universities are Yale University, University of Wisconsin, University of Florida and Ohio State University. The language is also being taught at the School of Oriental and African Studies, University of London and the University of Birmingham, both in Britain. ${ }^{20}$

He further highlights the efforts being made to sustain the tempo of this development, parts of which include sending of students from the Department of Education in United States of America to Obafẹmi Awolọwọ University, Ile-Ife to learn Yorùbá for eight weeks, since the year $1993,{ }^{21}$ as well as the research grant given by this same Department for the development of Yorùbá Living Dictionary on the internet. The site of this 
Dictionary is www.Yorùbá@georgiasouthern.edu. Another giant stride in this direction, according to him, is availability of series of articles in the Yorùbá Wikipedia, a free Yorùbá encyclopaedia on Yorùbá on internet, at www.yor.wikipedia.org ${ }^{22}$

It is also gratifying to note that students from United States of America are coming in batches to study Yorùbá Language in the Department of Linguistics and African Languages, University of Ibadan. ${ }^{23}$

\section{Varieties of the Yorùbá Language:}

The exact number of varieties existing in Yorùbá Language is yet to be discovered. Nevertheless, the most well known and documented being the Standard variety (that is, Standard Yorùbá, also referred to as literal Yorùbá, the Yorùbá koiné or common Yorùbá and at times simply as Yorùbá) which serves as a kind of Lingua franca among speakers of the other varieties of the language. It is the written form of the language. Indeed, it is the variety used for broadcasting, publication and in teaching in schools. ${ }^{24}$

Other varieties otherwise known as Yorùbá dialects are classified as follows according to the account of Adewọle (1987) ${ }^{25}$ quoting Oyelaran $(1978)^{26}$ :
a) West-Yorùbá (WY)
1) Òyó, İbàdàn, Ėgbá, Ohori-ifohin
2) Upper Ògùn (Ókè Òùn)
i) Saki, İjió
ii) Kétu, Sabẹe
3) Benin and Togo
Ifẹ̀ (Togo), Idasa, Manigi
b) South-East Yorùbá (SEY)
1) Ondo, $\grave{O} w \grave{o}$
2) İjẹbú
3) I İkálè, İlàjẹé
c) Central Yorùbá (CY)
Ilé-Ifẹe, İjẹsà, Ėkitì
d) Northern Eastern Yorùbá (NEY)
(1) İgbóminà, Kakanda, Ibọlo
(2) Јити, Bunu, Òwọrọ̆, Owe Egbe.

A close look at this classification shows a slight modification of what Adetugbo in his dialectological study earlier observed. ${ }^{27} \mathrm{He}$ views Yorùbá dialect continuum as consisting over fifteen varieties and thereafter classifies these varieties into three major dialect areas: Northwest; Central; and Southeast. However, it should be noted that with this classification, clear boundaries can never be drawn because peripheral areas of dialectal regions often have some similarities to adjoining dialects. The classification goes thus:

- $\quad$ North-West Yorùbá (NWY)

Abẹèkúta, İbàdàn, Ọyộ́, Ọ̀sun and Lagos State.

- $\quad$ Central Yorùbá (CY)

Igbomina, Ifọ̀, Èkìtì, Ẹọ̣n and İjẹsà areas.

- $\quad$ South-East Yorùbá (SEY)

Òkìtìpupa, Ondo, Ộwọ̀, Sagamu and part of İjệbú.

Of all these, the standard Yorùbá is said to be quite close to the Òyọ́ dialect. This, according to scholars is not unconnected with the advantages it has over all others. These include the fact that Ọyọ́ Empire happened to be the largest and most powerful of the kingdoms established by the Yorùbás. ${ }^{28}$ Legend also has it that the Alaafin of Ọyọ́ (that is, one of the most important Yorùbá kings) wielded so great a power in the past that other kings in Yorùbá land were paying homage to him. ${ }^{29}$

In addition, the influence of the late Bishop Ajayi Crowther, an Oyo-Yorùbá, on how Yorùbá language was reduced to writing could be said to have played a major role in the matter,${ }^{30}$ hence, the decision to adopt the Ọyọ́ dialect orthography in respect of the select Yorùbá proverbs in this work. 


\section{Influence of Arabic on the Yorùbá Language and Culture}

This is not an attempt to re-open an age long controversial statement made by Rev. Samuel Johnson, the Yorùbá clergyman whose History of the Yorùbás was published in 1921, that Yorùbá race emanated from amongst the Arabs. According to him, the Yorùbás are said to have sprung from Lamurudu one of the kings of Mecca whose offsprings were Oduduwa, the ancestor of the Yorùbá, the kings of Gogobiri and the Kukawa, two tribes in the Hausa country. ${ }^{31}$ Johnson assumption can be controverted for his assertion that the reign of Lamurudu - Namurudu (a dialectic modification of the name Nimra) appeared to have been a considerable time after Prophet Muhammad (P.B.O.H.). What a wrong assumption! The former had reigned during the time of Prophet Ibrahim (A.S.W) while the latter came centuries later.

Johnson also tried to link the origin of the term 'Yorùbá' to Yarba, the first permanent settlement in Africa, of the supposedly descendant of Nimrod (Phoenicians) who were led in war to Arabia, settled there and thereafter driven by a religious persecution to Africa. He maintained that Yarba is the same as Yarriba, the Hausa's term for Yorùbá. ${ }^{32}$ Another source also reveals that the term 'Yorùbá' has its origin from the phrase, " $y i$ o ru ebo" or "yorubo" meaning "(he) will make sacrifices." Here, reference is being made to Ebo (the ritual sacrifice that complements Ifá divination) in Yorùbá spirituality. ${ }^{33}$

Arabic, being the language of the Qur'an and a vehicle of Islamic culture has influenced the languages of the Muslim peoples of which the Yorùbás are not an exception. This has invariably resulted in syntactical and lexical borrowings. ${ }^{34}$ Among other languages that have been tremendously influenced by Arabic are: Asia, Persia, Turkish, Urdu and Malay. Other African languages that acquired loans from Arabic words and expressions include: Somali, Swahili, Madinka, Wolof, Haúsá, Fulfude and Kànúrí.

This act of borrowing shows that Yorùbá language is indeed a living language. Salami (1982) has long observed this when he wrote:

One of the characteristics of a living language is that it must reflect the changes in the culture and life of its speakers in order to keep pace linguistically with the different developments of modern life - in social and religious matters, in commerce and industry, science and technology, etc. In order to fulfil this vital function, a language must, among other things, extend its vocabulary by employing to a greater or lesser extent the following three methods, (a) creation of new words out of its morphemic and phonemic resources, (b) extension of the use of words already in its vocabulary, and (c) borrowing words from other languages. ${ }^{35}$

When closely observed, one notes that Yorùbá language has employed the last method. That is, borrowing words from other languages with which its speakers have had appreciable contacts far more than the other two methods highlighted above.

Besides Arabic language, notable among other languages from which Yorùbá has borrowed heavily are Hausa and English. Salami (1982) has attributed that of English language to the activities of Christian missionaries (mostly native speakers of English from either British or America) whose influence on education among the Yorùbás, have been remarkable. ${ }^{36}$

He further observed that the unique position of the British who ruled for almost a century, over Nigeria, of which the Yorùbá land is a part has redounded the influence which English language has had and continues to have on Yorùbá language. ${ }^{37}$

At this juncture, it should be remembered that the British brought Christianity religion through their missionary activities, but prior to the coming of the British, Islam had already established itself in the Northern as well as the Western parts of Nigeria and consequently, many Arabic words and expressions had already gained in-road into the Yorùbá language perhaps in the early days of Islam in Yorùbá land. This explains why such words and expressions are often used by the Yorùbá regardless of their religious inclinations, be they Muslims, Christians or traditional worshippers. ${ }^{38}$

The following Yorùbá saying, in the words of Malik, citing Gbadamọsi corroborates the fact that the history of the contact between Yorùbás and Arabic through Islam has been a very long one:

$$
\begin{aligned}
& \text { Ayé l'abá 'fá } \\
& \text { Ayé l'abá 'mọle } \\
& \text { Ösán gangan nigbàgbó } \\
& \text { Wolé dé. }
\end{aligned}
$$

$$
\begin{aligned}
& \text { We met Ifá (the Yorùbá traditional religion) } \\
& \text { in the world } \\
& \text { We met Islam in the world, but } \\
& \text { Christianity came later in the day. }{ }^{39}
\end{aligned}
$$

\section{Arabic Loan Words in the Yorùbá Language}

As we have discussed earlier, Arabic language has had a considerable influence on Yorùbá language. The contact of the Yorùbá and Arabic through Islam has affected the social, cultural and commercial life of the 
Yorùbá. This is not unusual; it is indeed a general linguistic trend not peculiar to Yorùbá alone. E. Sapir has long observed:

Languages, like cultures, are rarely sufficient unto themselves. The necessity of intercourse brings the speakers of one language into direct or indirect contact with those of neighbouring or culturally dominant languages. The intercourse may be friendly or hostile. It may move on the humdrum plane of business and trade relations or it may consist of borrowing or interchange of spiritual goods art, science, religion ... The simplest kind of influence that one language may exert on another is the 'borrowing' of words. When there is cultural borrowing there is always the likelihood that the associated words may be borrowed too. ${ }^{40}$

It is gratifying that what Salami (1982) observes of the 'intercourse' between the British and the Yorùbás is in conformity with that of the Arabs and the latter. It can also be described as a 'friendly' one, moving on the humdrum plane of business and trade relations' and consisting of 'interchange of spiritual goods'.

While Ogunbiyi identifies eight subject matter groups in which the Yorùbá language has borrowed words and expressions from Arabic language, ${ }^{41}$ Malik, specifically makes a long list of about fifty-eight Arabic loan words that have come into Yorùbá usage which are found in Yorùbá Dictionaries. ${ }^{42} \mathrm{He}$ also focuses attention on some Arabic loan words which are frequently used by Yorùbá speakers in their daily speech, in Yorùbá poetry $(E w i)$, as well as in Yorùbá radio and television news bulletins and advertisement. He also makes reference to some Arabic words used in the translation of various editions of Yorùbá Bible. ${ }^{43}$

Samples of Arabic loan words used in various editions of the Yorùbá Bible are: العافية (al- 'Afiyah), $(a l-D u ' \bar{a})$ and $g(w a ' z)$ used in the following sentences respectively ${ }^{44}$ :

1) “Jésù pàdé wọn, ó wí pé Àlàfià"

"Jesus met them and said "Hail"

The Yorùbá word "Alááfià" is a loan word from the Arabic word al- 'Áfiyah meaning "good health; well-being". It is used in Matteu, 28:9, Samuel, 3:21 and İwé Òwe 17:1

2) "Gbó àdúrà mi, Olúwa"

"Hear my prayer, O Lord"

The Yorùbá word adua is borrowed from the Arabic word $a l-D u$ ' $a$ meaning, "prayer; supplication". It is used in Orin Dáfidì, 102:1, 65:2 and 142:8

3) "Ó sì wí fúnwonpé, e jẹ kí á lo sí ilú mírànkí èmi ó le wasunibẹ pẹlu’"

"And he said to them; let us go onto the next towns that I may preach there also"

The Yorùbá word ìàaśù is borrowed from the Arabic word wa $z$ meaning "sermon; preaching".

The word is used in Marku, 1:38 and 1:7 and also in Matteu, 10:7

Abubakre (2002) also states some Arabic words loaned to Yorùbá for a couple of centuries which are now found in the Bible of Samuel Ajayi Crowther and his book of Grammar, as well as the Oxford Dictionary of 1950 and R.C. Abraham Dictionary of Modern Yorùbá of $1958 .^{45}$

He enumerates nine words which are, according to him, taken for granted. ${ }^{46}$ In his list, only one item tallies with

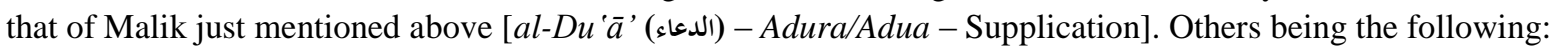

$\begin{array}{ll}\text { Arabic } & \text { Yorùbá } \\ \text { al- } A m r & \text { àlámọrí } \\ \text { Allāhu Rabbì } & \text { Áláù ràbí } \\ \text { khilāfah } & \text { àlèéfà } \\ \text { al-Barakah } & \text { àlùbáríkà } \\ \text { ar-Ra'd } & \text { àrá } \\ \text { ar-Rizq } & \text { arísikí } \\ \text { darūrī } & \text { làlúrí } \\ \text { sabab } & \text { sábàbi }\end{array}$

Meaning
matter
my Lord, Allah
caliphate/ruling
blessing
thunder
provision, wealth
necessity
cause.

Abubakre's explanation on this selection is very educative and informative. He observes the manner with which Yorùbá treat the extraneous syllabic features in the borrowed words from Arabic, the like of, 
consonant cluster and consonant close. In Arabic al-Barakah> àlùbáríkà in Yorùbá, he maintains that the consonant is broken with an epenthetic vowel, while the Arabic al-'Amr àlámòrí in Yorùbá, the consonant close is opened with an anaptytic vowel. ${ }^{47}$

He further explains switching from Yorùbá language to Arabic at the sentential level. He maintains that switching is a circulated attempts by the literary and non-literary popular artists especially the singers and the preachers in order to impress their audience that they have some knowledge of Arabic.

According to him, this act may also be an attempt to demonstrate their religious affiliation or to communicate with God in a theatrical manner of wishing the audience well. He cites an example in a record of Sunny Ade, a Christian artist, who switches to Arabic in order to impress his Muslim fans and also as an emphasis by saying the same thing in different languages or stating the same concepts as Muslims and Christians would have them stated. He quoted Sunny Ade as saying:

$$
\begin{aligned}
& \text { Bí İgbàgbó bá mí a wí } \\
& \text { Á ní modúpẹ Olúwa } \\
& \text { Bí İmàle mí a wí á ní } \\
& \text { Walillahi lii amudu (wallillahi 'l-hamd) } \\
& \text { Amudawaashukura (Hamdan wa shukran) }
\end{aligned}
$$

When a Christian wishes to express (thanks)

He says I thank (you o!)

When a Muslim wishes to express (thanks) he says

To God belongs praise

I offer praise and thanks (to God) ${ }^{48}$

He reiterates further that this sort of switching is also predominant in the lyrics of Muslim artists such as Haruna Ishọla in Ápàlà, Yusuf Ọlatunji and Sanusi Aka in Sakara as well as Sikiru Ayinde and Kollington Ayinla in Fuji.

It might also be interesting to note that the Yorùbá traditional oral literature contains some notion involving Arabic and Islam. Abubakre, citing Wande Abimbọla quoted the following Esè̀-Ifá which includes two Arabic words.

$$
\begin{aligned}
& \text { Ìgbònwó-méjéèjì ò seé-gbẹrù sájà } \\
& \text { á difá fún alukaadi } \\
& \text { Omọ Aala }
\end{aligned}
$$

The two elbows cannot lift a load to the ceiling cast Ifá for Alukaadi The son of Allah

In this context, the Arabic word for judge, al-Qadi and the word Allah not minding the sacrilege of attributing son to Him are naturalized. ${ }^{50}$

Samples also abound in Yorùbá literature texts which attest to enormous amount of Arabic loan words and expressions in Yorùbá language. The works like Atótó-Arére, Ảbíkú s'olóògùn d'èké and Gbóbaníyì written by a trio of the contemporary Yorùbá novel writers, Oladẹjọ Okediji, OluOwolabi and Oladipọ Yemitan respectively are not an exemption in this regard. In this sense, I have chosen the following sentences in which there are Arabic loan words for illustration:

(1) ...kádàrá mi ni mò ń bá kiri, ohun tí ẹ bá mi se ní àdúrà k’Édùmárè jẹ k'ọmọ ó gbèyìn mi...

I am going all about with my destiny; the prayer you should be offering for me is that may God let me leave a child behind.

The two Yorùbá words, kádàrá and àdúrà are borrowed from the Arabic word qadar and $\boldsymbol{a l}-\mathbf{D} \boldsymbol{u} \boldsymbol{a}^{\boldsymbol{a}}$, meaning destiny; fate and prayer; supplication respectively.

\section{Ta ló mo iye ènìyàn tí obìnrin yì ti bà láyé jẹ? Ta lọ mo iye ẹni tó ti ránsí àlùkiámọ. ${ }^{52}$}

Who knows how many people this woman has spoilt their lives? Who can tell how many people she has sent to the world beyond?

The Yorùbá word àlùkiámọ is a borrowed word from Arabic word al-Qiyamah meaning, heaven: resurrection; the day of final judgement. 
(That) Bolanle has disappointed him, she has really dashed his hope.

The Yorùbá word tànmộ is a borrowed word from Arabic word tammā' meaning hope; high-aiming.

$$
\text { Àwọn onílù ń mú wọn kì lộkọộkan, àwọn jànmọọ náà sì ń náwó bi elệdà. }{ }^{54}
$$

The drummers were praising them one after the other, and the gang was spending lavishly.

The Yorùbá word jànmọ $\boldsymbol{o}$ is a borrowed word from Arabic word jamāe ah meaning group (of people); band; gang; party; troop; community.

\section{Àdúrà jẹ-ó ju òògùn lọ. İgbà yì ni Bámdélé mọ̣. ${ }^{55}$}

Prayer is more efficient than medicine. Bamdele now realised. supplication.

The Yorùbá word Àdúrà is a borrowed word from Arabic word $\boldsymbol{a l}-\boldsymbol{D} \boldsymbol{u} \mathfrak{e} \overline{\boldsymbol{a}}$, meaning prayer;

\section{Irètí wa nipe e ó máa fi àdúrà rànwá lọwọ lójoojúmọ. ${ }^{56}$}

Our expectation is that you will always remember us in prayer.

\section{E șeun gbogbo èyin tí e pé lónìi. Kí àlàáfíà Olọrun máa bá gbogbo yín gbé. ${ }^{57}$}

Thanks to you people here present today. May the peace of Allah abide with you.

The Yorùbá word àlàáfià is a borrowed word from Arabic word al- ‘Afiyah meaning al-Salām, the peace (of Allah) in this context.

\section{Conclusion}

In the foregoing, some insights have been given to Arabic and Yorùbá languages, their speakers, as well as the varieties of the two languages vis-à-vis the standard and colloquial ones. Also explained in this paper are possible influence of Arabic language on Yorùbá language and culture, and Arabic loan words frequently used by Yorùbá speakers in their daily speech, and those found in the Bible, as well as in selected Yorùbá literature texts which attest to enormous amount of Arabic loan words in Yorùbá language.

\section{References}

[1]. D.Y. Terry, Arabic: Background history in Arabic language history, (Spring 1999). Retrieved Jan. 07, 2010 from, http://www.arabicstudies.edu/arabiclangrev.html

[2]. S. Habeeb, The odyssey of Arabic language and its scripts,(n.d.), 3. para. 9. Retrieved Jun. 27, 2011 from http://www.alhewar.com/habeeb salloum arabic language.htm

[3]. P.K. Hitti, History of the Arabs. $10^{\text {th }}$ ed. (Hong Kong: Macmillian Publishers Ltd. 1970), 4

[4]. S. Habeeb, The odyssey of Arabic language and its scripts, (n.d.), 4. para. 1.

[5]. S. Habeeb, The odyssey of Arabic language and its scripts, (n.d.), 2. para. 2.

[6]. See J. Carmicheal, The Shaping of the Arabs, (New York: Macmillan, 1967).

[7]. S. Habeeb, The odyssey of Arabic language and its scripts, (n.d.), 3. para. 7.

[8]. S. Habeeb, The odyssey of Arabic language and its scripts, (n.d.), 4. para. 2.

[9]. S.H.A. Malik, A contrastive study of the verbal patterns in standard Arabic and spoken Egyptian Arabic. PhD Thesis. Department of Arabic and Islamic Studies. University of Ibadan, (1976), 14-17.

[10]. J. Dickins, et al.Thinking Arabic translation: A course in translation method: Arabic to English, (London: Routledge, 2010$)$, 167.

[11]. S. Habeeb, The odyssey of Arabic language and its scripts, (n.d.), 1. para. 3.

[12]. S. Habeeb,The odyssey of Arabic language and its scripts(n.d.), 1. para. 2

[13]. O.A. Lawrence, The Yorùbá language: Published works and Doctoral Dissertation, 1843-1986, 2 ${ }^{\text {nd }}$ ed. (Burke Verlag, 1987), 11

[14]. Tai Solarin, an educationist, had earlier used a similar term "LOOBO" to describe the states controlled by the defunct unity party of Nigeria (UPN). "LOOBO" according to him stands for Lagos, Ondo, Ogun, Bendel and Oyo States of Nigeria. In the same vein, Adewole (1987) employed the term "LOOKO" to explain the states in which Yorùbá language is spoken. These are: Lagos, Oyo, Ogun, Kwara and Ondo states of Nigeria. This latest use has only concentrated on states within the old Western Region and also incorporated the two newly created states; Osun and Ekiti from Oyo and Ondo respectively.

[15]. O.O. Akinkugbe, A comparative phonology of Yorùbá (dialects), Isekiri and Igala, PhD Thesis. The Department of Linguistics and African Languages University of Ibadan, (1978), 22. See also J.A. Atanda, An Introduction to Yorùbá History, (Nigeria: I.U.P, 1980), 1

[16]. O.O. Akinkugbe, A comparative phonology of Yorùbá (dialects), Isekiri and Igala, (1978), 22. 
[17]. L.D. Turner, The role of folklore in the life of the Yorùbá of south western Nigeria. Monograph series on Languages and Linguistics 11-12: Report of the $9^{\text {th }}$ annual round table meeting on Linguistics and Language study. Ed. W.M. Austin. Georgetown: The institute of Foreign Service, Georgetown University, (1958), 45.

[18]. C.M. Hunt, Oyotunji village: Yorùbá movement in America. Thesis. West Virginia University, (1977), 17, 51.

[19]. M.H. Watkins, TheYorùbá phoneme. Studies in linguistics in honour of George L. Trager ed. M.E. Smith, (The Hague: Mouton, 1972), 380

[20]. L.O. Adewole, Issues in linguistics and Yorùbá language. Obafemi Awolowo University inaugural lecture series 202,(Ile-Ife: ObafemiAwolowo University Press Limited, 2007), 23.

[21]. L.O. Adewole, Issues in linguistics and Yorùbá language, (2007), 23.

[22]. L.O. Adewole, Issues in linguistics and Yorùbá language, (2007), 23.

[23]. An oral interview with Prof. P.A. Ogundeji, former Dean of Arts, University of Ibadan, aged 58, in his office on Mon. Aug. 15, 2011.

[24]. O.O. Akinkugbe, A comparative phonology of Yorùbá (dialects), Isekiri and Igala, (1978), 22.

[25]. L.O. Adewole, The Yorùbá language: Published works and Doctoral Dissertations 1843-1986. African linguistic bibliographies: Vol. 3. (Helmut BuskeVerlag Hamburg, 1987), 11.

[26]. O.O. Oyelaran, Linguistics speculations on Yorùbá history. Department of African Languages and Literatures Seminar Series 1: (1978), 626.

[27]. A. Adetugbọ, Towards a Yorùbá dialectology. Afọlayan (ed.): Yorùbá Language and Literature, (1982), 207-224. Retrieved Sept. 20, 2007, from http://en.wikipedia.org/wiki/Yorùbá language. (This classification is said to be originated from Adetugbọ's 1967 PhD Thesis: The Yorùbá language in Western Nigeria: Its major Dialect Areas, at Columbia University). See also A. Adetugbọ, The Yorùbá Language in Yorùbá History, in Biobaku, S.O (ed.): Sources of Yorùbá History, (1973), 176-204.

[28]. J.A. Atanda, An introduction to Yorùbá history, (Nigeria: U.I.P, 1980), 32.

[29]. S.H.A. Malik, A contrastive study of the verbal patterns in standard Arabic and spoken Egyptian Arabic, (1976), 21.

[30]. Standard Yorùbá has its origin in the 1850's, when this man, Samuel Ajayi Crowther, a native Yorùbá and the first African Bishop, published a Youth grammar and started his translation of the Bible.

[31]. J. Samuel, The history of the Yorùbá, (Lagos: CSS Limited, 2001), 3.

[32]. J. Samuel, The history of the Yorùbá, (2001), 6

[33]. Yorùbá Language - Wikipedia, the free encyclopedia. Retrieved Sept. 20, 2007, from http://en.wikipedia.org/wiki/Yorùbá language.

[34]. S.H.A. Malik, Arabic, the Muslim prayers and beyond.University of Ibadan Inaugural Lecture. Ibadan: Ibadan University Press, (1999), 23.

[35]. A. Salami, Vowel and consonant harmony and vowel restriction in assimilated English loan words in Yorùbá. Yorùbá Language and Literature. AdebisiAfọlayan Ed. (Nigeria: University of Ife Press and University Press Limited, 1982.), 118.

[36]. A. Salami, Vowel and consonant harmony and vowel restriction in assimilated English loan words in Yorùbá, (1982), 118.

[37]. A. Salami, Vowel and consonant harmony and vowel restriction in assimilated English loan words in Yorùbá, (1982), 119.

[38]. S.H.A. Malik, Arabic, the Muslim prayers and beyond,(1999), 30.

[39]. S.H.A. Malik, Arabic, The Muslim prayers and beyond,(1999), 31. cf. T.G.O. Gbadamosi, The growth of Islam among the Yorùbá, 1841-1908, (London: Longman, 1978), 16.

[40]. E. Sapir, Language. (New York: Harcourt, Brace and World Inc.,1921), 192.

[41]. S.H.A. Malik, Arabic, The Muslim Prayers and Beyond,(1999), 26. cf. I.A. Ogunbiyi, Arabic Loan words in the Yorùbá language. Arabic Journal of Language Studies 3 (1),(1984), 161-180.

[42]. S.H.A. Malik, The impact of Arabic on the linguistic and cultural life of the Yorùbá people. Language in Nigeria. Kọla Owolabi Ed. (Ibadan: Group publishers, 1995), 424-439. cf. S.H.A. Malik, Arabic, The Muslim prayers and beyond, (1999)

[43]. S.H.A. Malik, Arabic, The Muslim prayers and beyond,(1999), 23-31.

[44]. S.H.A. Malik, Arabic, The Muslim prayers and beyond,(1999), 29-30. See also S.H.A. Malik, The impact of Arabic on the linguistic and cultural life of the Yorùbá people,(1995), 431-432.

[45]. R.D. Abubakre, Survival of Arabic in difficult terrains. The Fifty-Eight Inaugural Lecture. University of Ilorin, (Ilorin: Unilorin Press, 2002), 25.

[46]. R.D. Abubakre, Survival of Arabic in difficult terrain, (2002), 25-26.

[47]. R.D. Abubakre, Survival of Arabic in difficult terrains,(2002), 25-26. (For more analysis on this and similar ones, see R.D. Abubakre, "The learning of Arabic by Yorùbá speakers" in JOLAN Journal of Linguistic Association of Nigeria 2: (1983-4), 143152 .

[48]. R.D. Abubakre, Survival of Arabic in difficult terrains,(2002), 26.

[49]. Cited by W. Abimbola, The literature of the Ifa cult. S.O. Biobaku Ed. (OUP,1973), 58. cf. R.D. Abubakre, Survival of Arabic in difficult terrains,(2002), 27-28.

[50]. R.D. Abubakre, Survival of Arabic of difficult terrains, (2002), 28.

[51]. O. Olu, Abikus'ologund'eke,(Lagos: Macmillan Nigeria Publishers Ltd, 1988), 30-31.

[52]. O. Okediji, Atoto Arere, (Ibadan: University Press Limited, 1981), 183.

[53]. O. Okediji, Atoto Arere,(1981), 160

[54]. O. Okediji, Atoto Arere,(1981), 120.

[55]. O. Yemitan, Gbobaniyi,(Ibadan: University Press Limited, 1988), 91.

[56]. O. Yemitan, Gbobaniyi,(1988), 49.

[57]. O. Olu, Abiku s'ologun d'eke,(1988), 79. 